\title{
ОБ ИСКЛЮЧЕНИИ ИЗ ОСОБЕННОЙ ЧАСТИ И ВЫНЕСЕНИИ В ОБЩУЮ ЧАСТЬ УК РФ ОТДЕЛЬНЫХ КВАЛИФИЦИРУЮЩИХ ПРИЗНАКОВ ПРЕСТУПЛЕНИЙ ПРОТИВ ЛИЧНОСТИ
}

\section{ON EXCLUDING CERTAIN QUALIFYING FEATURES OF CRIMES AGAINST THE PERSON FROM THE SPECIAL PART AND MAKING THEM PART OF THE CRIMINAL CODE OF THE RUSSIAN FEDERATION}

A. Motin

Summary. The article is devoted to the analysis of differentiation of criminal responsibility for crimes against the person by means of qualifying features. Consider these potential areas for quality improvement of the system of aggravating circumstances as the exception of a few features from the Special part of the criminal code and the imposition of certain characteristics in the General part of the Code.

Keywords: differentiation, qualifying feature, criminal liability, totality, recidivism, qualification.

\author{
Мотин Анатолий Владимирович \\ К.ю.н., Адвокат, Палата адвокатов Самарской \\ области (2. Самара) \\ amotin85@yandex.ru
}

Аннотация. Статья посвящена анализу дифференциации уголовной ответственности за преступления против личности посредством квалифицирующих признаков. Рассмотрены такие потенциальные направления качественного совершенствования системы квалифицирующих признаков как исключение отдельных признаков из Особенной части УК РФ и вынесение некоторых признаков в 0бщую часть Кодекса.

Ключевые слова: дифференциация, квалифицирующий признак, уголовная ответственность, совокупность, рецидив, квалификация.
$\mathbf{K}$ валифицирующие признаки должны характеризовать единичное преступление и не пересекаться с институтом множественности преступлений и характеристикой личности виновного. С этой точки зрения вызывает сомнение использование в УК РФ таких признаков, как «совершение преступления в отношении двух или более лиц», «совершение преступления, сопряженного с иным преступлением», «совершение преступления лицом, ранее судимым».

Совершение преступления в отношении двух или более лиц указано законодателем в числе признаков составов преступлений, предусмотренных ст.ст. 105, 107, 109, $110,110.1,111,112,117,121,122,126,127,127.1,127.2$, $134,135,151.2$ УК РФ. Вопросы толкования и применения этого признака раскрыты в двух постановлениях Пленума Верховного Суда РФ (по делам об убийстве и о половых преступлениях), согласно которым, исходя из положений ч. 1 ст. 17 УК РФ, признается, что совершение преступления в отношении двух или более лиц, совершенное одновременно или в разное время, не образует совокупности преступлений и подлежит квалификации как одно преступление по соответствующему пункту ста- тьи Особенной части УК РФ, при условии, что ни за одно из этих преступлений виновный ранее не был осужден ${ }^{1}$.

Такое толкование изначально было предложено в 2008 году применительно к убийствам и стало реакцией высшей судебной инстанции России на исключение признака неоднократности из числа квалифицирующих признаков убийства и было продиктовано, как представляется, стремлением обеспечить равенство граждан перед законом и справедливость в ситуации, когда в результате действий виновного смерть причиняется двум или более лицам при различном содержании вины. Вместе с тем, некоторыми специалистами оно оценивается критически.

1 Постановление Пленума Верховного Суда РФ от 27.01.1999 № 1 «О судебной практике по делам об убийстве (ст. 105 УК РФ)» // Бюллетень Верховного Суда РФ. - 1999. - № 3; Постановление Пленума Верховного Суда РФ от 04.12.2014 № 16 «О судебной практике по делам о преступлениях против половой неприкосновенности и половой свободы личности» // Бюллетень Верховного Суда РФ. - 2015.— № 2. Аналогичные предписания содержались в проекте постановления, посвященного квалификации преступлений против свободы, но в окончательный вариант постановления они не вошли. См.: Постановление Пленума Верховного Суда РФ от 24.12.2019 № 58 «О судебной практике по делам о похищении человека, незаконном лишении свободы и торговле людьми» // Бюллетень Верховного Суда РФ.— 2020.— № 3. 
Ю.Е. Пудовочкин пишет: «Более предпочтительной представляется рекомендация, содержавшаяся в первоначальной редакции постановления Пленума от 27.01.1999 № 1, согласно которой по п. «а» ч. 2 ст. 105 УК РФ следовало квалифицировать убийство двух или более лиц, если действия виновного охватывались единым умыслом. Умышленное причинение смерти двум или более лицам, не связанное единством умысла, мотивов и намерений, на наш взгляд, целесообразно квалифицировать по совокупности преступлений» ${ }^{1}$. К более радикальному выводу о необходимости исключения рассматриваемого признака из закона пришла на основании глубокого исследования этой проблемы с акцентом на вопросы квалификации и назначения наказания Н. А. Лопашенко².

Такой вывод небезоснователен. К нему сподвигает и прикладной, и теоретический анализ проблемы. Есть все основания считать, что $n$. «a» $4.2 \mathrm{~cm} .105 \mathrm{VK} \mathrm{РФ}$ являет собой исключительно искусственную и нежизнеспособную конструкиию, в рамках которой под видом единичного преступления скрывается совокупность преступлений. В качестве доказательств, основанных на практике применения данной нормы, можно привести следующие:

- различный статус потерпевших при совершении преступления в отношении двух лиц, при котором посягательство на одно лицо охватывается специальной нормой (например, при совершении деяний, предусмотренных ст. 105 и ст. 317 УК РФ), требует оценки содеянного по правилам совокупности ${ }^{3}$,

- два убийства, из которых одно совершено при наличии привилегированных признаков (например, при превышении пределов обороны), квалифицируется по правилам совокупности ${ }^{4}$,

\footnotetext{
1 Комментарий к Уголовному кодексу Российской Федерации (постатейный). В 2 т. Т. 1. / под ред. А. В. Бриллиантова.—Изд. 2-е.- М.: Проспект, 2015.С. 375. К этому же мнению склоняется А.Н. Попов, см.: Комментарий к Уголовному кодексу Российской Федерации. В 4 т. Т. 2. Особенная часть. Разделы VII — VIII / отв. ред. В. М. Лебедев.—М.: Юрайт, 2017.-C. 26. На такой квалификации настаивает Д. В. Васяев, признавая убийство двух или более лиц продолжаемым преступлением (Васяев Д. В. Уголовная ответственность за убийство с учетом его мотива и цели: проблемы правотворчества и правоприменения: автореф. дисс. ... канд. юрид. наук. - Самара, 2014.— С. 9). В этом отношении интересно отметить, что, к примеру, в немецкой практике конструкция продолжаемого преступления в целом была признана неконституционной (см. об этом: Фристер Г. Уголовное право Германии. Общая часть. - 5-е изд.-М.: Инфотропик, 2013.-С. 665).

2 Лопашенко Н. А. Убийства.— М.: Юрлитинформ, 2013.—C. 216-238.

${ }^{3}$ Верховный Суд РФ. Дело № 18-АПУ19-30. Апелляционное определение от 21.01.2020. Дискуссию о правилах квалификации таких ситуаций см., например: Попов А.Н. Убийства при отягчающих обстоятельствах.-СПб.: Юридический центр Пресс, 2003.- С. 55-58.

${ }^{4}$ См. п. 16 постановления Пленума Верховного Суда РФ от 27.01.1999 № 1 «О судебной практике по делам об убийстве (ст. 105 УК РФ)» // Бюллетень Верховного Суда РФ. - 1999. - № 3; Верховный Суд СССР. Определение Судебной коллегии от 22.12.1967 по делу Кулиева Р. Б. // Бюллетень Верховного Суда СССР.— 1968.- № 1.
}

- различные стадии совершения двух убийств (например, оконченное убийство и покушение на убийство) и различные роли при их совершении (например, исполнительство и подстрекательство) оцениваются по правилам совокупности ${ }^{5}$,

- срок давности по каждому из убийств исчисляется самостоятельно ${ }^{6}$,

- с позиций учения о множественности преступлений будет оценено убийство двух лиц, совершенное на территории различных государств,

- не применяется рассматриваемый признак в случае, когда после осуждения за преступление в отношении одного лица станет известно о том, что лицо до этого совершило еще одно такое же преступление в отношении другого лица,

- в отсутствие в статье УК РФ квалифицирующего признака «совершение преступления в отношении двух или более лиц», совершение этого преступления в отношении нескольких потерпевших образует совокупность преступлений․

Возможность признания совершения преступления в отношении двух или более лиц особой формой множественности теоретически обосновывается в специальных исследованиях, посвященных данному институту ${ }^{8}$. Не углубляясь в исследование темы множественности и места ситуаций совершения преступления в отношении двух или более лиц в системе форм множественности, констатируем основное: совершение преступлений в отношении двух или более лиц не может рассматриваться как единичное преступление. Т.А. Плаксина, на наш взгляд, совершенно права, когда пишет: «Состав убийства двух или более лиц сконструирован законодателем как характеризующийся тождественной многообъектностью сложный состав, объединяющий неопределенное

См. п. 5 постановления Пленума Верховного Суда РФ от 27.01.1999 № 1 «О судебной практике по делам об убийстве (ст. 105 УК РФ)» // Бюллетень Верховного Суда РФ.—- 1999.— - № 3; Верховный Суд РФ. Дело № 299-П13ПР. Постановление Президиума Верховного Суда РФ от 19.02.2014; Дело № 72АПУ 14-71. Апелляционное определение от 29.01.2015; Дело № 11-АПУ15-18. Апелляционное определение от 14.07.2015.

${ }^{6}$ Такой вывод однозначно следует из ранней практики применения п. «и» ч. 2 ст. 102 УК РСФСР 1960 г. «убийство, совершенное лицом, ранее судимым за убийство». Пленум Верховного Суда РФ указывал в свое время: «Убийство не может квалифицироваться по п. «и» ст. 102 УК РСФСР, если к моменту совершения убийства истек срок давности привлечения к уголовной ответственности за ранее совершенное преступление». См. п. 12 постановления Пленума Верховного Суда РФ от 22.12.1992 № 15 «О судебной практике по делам об умышленных убийствах» // Бюллетень Верховного Суда РФ.-1993.- № 3.

${ }^{7}$ Верховный Суд РФ. Дело № 19-АПУ14-36СП. Апелляционное определение От 11.12.2014.

${ }^{8}$ См., например: Малков В.П. Институт множественности преступлений в доктрине и уголовном законодательстве России // Актуальные проблемы экономики и права. - 2008. - № 4.- С. 179-192; Шкредова Э.Г. Формы множественности преступлений в современной уголовно-правовой доктрине // Журнал Российского права.— 2012.— № 9.- С. 50-54. 
множество тождественных преступлений. Однако социальная потребность в уголовно-правовой охране совокупности основных объектов убийства, каждому из которых причиняется вред, материализующийся в виде смерти потерпевшего, в силу ряда причин не способна получить юридическое выражение в квалифицирующем убийство обстоятельстве, а может быть реализована лишь через институт совокупности преступлений» ${ }^{\text {. }}$.

Еще один квалифицирующий признак, отражающий множественность, - сопряженность одного преступления с другим. Он непосредственно предусмотрен в ч. 2 ст. 105 УК РФ в нескольких ее пунктах. Правила квалификации убийств при наличии сопряженности с другими преступлениями установлены в упомянутом постановлении Пленума Верховного Суда РФ и предполагают обязательную квалификацию содеянного с учетом положений закона о совокупности (в том числе в ситуациях, когда «сопряженное» преступление не совершено по независящим от лица обстоятельствам) ${ }^{2}$. Подтверждены такие правила и Конституционным Судом РФ³. Однако в науке обосновываются и иные суждения на этот счет, отталкивающиеся от идеи признания рассматриваемой конструкции проявлением единичного сложного (составного) преступления 4 .

Такая ситуация настоятельно требует объяснения. В частности, признавая необходимость квалификации содеянного в рассматриваемых случаях по правилам совокупности, надо обосновать, что убийство, сопряженное с некоторыми иными, прямо указанными в законе преступлениями, обладает повышенной общественной

\footnotetext{
${ }^{1}$ Плаксина Т. А. Социальные основания квалифицирующих убийство обстоятельств и их юридическое выражение в признаках состава преступления: автореф. дисс. ... д-ра юрид. наук.-Томск, 2006.- С. 8-9. 2 Верховный Суд РФ. Дело № 49-О09-116СП. Определение Судебной коллегии по уголовным делам от 3.09.2009; Дело № 66-УД14-3. Определение суда кассационной инстанции о 17.02.2015.

з Определение Конституционного Суда РФ об отказе в принятии к рассмотрению жалобы гражданина Филиппова Виктора Сергеевича на нарушение его конституционных прав частью первой статьи 17, пунктом «з» части второй статьи 105 и пунктом «в» части четвертой статьи 162 Уголовного кодекса Российской Федерации от 17 ноября 2011 г. № 1569-О; Определение Конституционного Суда РФ об отказе в принятии к рассмотрению жалобы гражданина Пономарева Ивана Александровича на нарушение его конституционных прав частью первой статьи 17 и частью третьей статьи 62 Уголовного кодекса Российской Федерации от 17 февраля 2015 г. № 307-О; Определение Конституционного Суда РФ об отказе в принятии к рассмотрению жалобы гражданина Глушкова Дмитрия Анатольевича на нарушение его конституционных прав частью первой статьи 17 Уголовного кодекса Российской Федерации от 24 сентября 2012 г. № 1663-О.

${ }^{4}$ Иногамова-Хегай Л.В. Концептуальные основы конкуренции уголовноправовых норм.- М.: Норма, 2015.-С. 166-172; Щепельков В.Ф. Уголовный закон: преодоление противоречий и неполноты.- М.: Юрлитинформ, 2003.- С. 160-161; Иванов Н.Г. К вопросу о квалификации «преступлений сопряженности» // Вестник Академии Генеральной прокуратуры Российской Федерации. Научно-практический журнал.- М., 2007.— № 2 (2).-C. 38-42.
}

опасностью, учет которой не может быть осуществлен в рамках применения института совокупности преступлений и требует конструирования квалифицированного состава преступления.

Попытки обоснования соответствующего законодательного решения, как правило, сводятся к характеристике умысла, цели и мотива деятельности виновного 5 . Не оспаривая такого подхода, заметим все же, что: а) для оценки этих обстоятельств в законе уже предусмотрен признак «убийство с целью скрыть другое преступление или облегчить его совершение»; б) соответствующие параметры вины меняются в случае совершения убийства, сопряженного с любым преступлением, а не только с изнасилованием, насильственными действиями сексуального характера, похищением человека, разбоем, вымогательством или бандитизмом. Учитывая это, Н.Н. Коротких верно пишет, что «идея сочетания нескольких преступлений в рамках состава убийства или в законодательных конструкциях других составов нецелесообразна по причине отсутствия какой-либо логики в выборе самих преступлений, на основе которых должно происходить усиление репрессии» ${ }^{6}$.

Осознавая указанные обстоятельства, наука предложила два противоположных решения: унифицировать исследуемые квалифицирующие признаки и расширить их содержание в рамках единой конструкции «убийства, сопряженного с иным преступлением ${ }^{7}$ либо вовсе отказаться от использования в законе такого признака ${ }^{8}$. Последнее предложение представляется более обоснованным. В поддержку его отметим дополнительно, что признание исследуемой конструкции особой разновидностью совокупности, которая учтена законодателем, но вместе с тем требует для квалификации института множественности, порождает безусловную «двойную» ответственность, ког-

Бородин С.В. Преступления против жизни.-М.: Юристъ, 1999.-С. 102, 152; Арсанукаев И.С. Криминологическое и уголовно-правовое исследование предупреждения убийств, сопряженных с другими преступлениями: дисс. канд. юрид. наук.- М., 2012.-С. 37-38.

${ }^{6}$ Коротких Н.Н. Теоретические и прикладные проблемы учения о множественности преступлений: уголовно-правовое и уголовноисполнительное исследование: автореф. дисс. ... д-ра юрид. наук.Екатеринбург, 2016.-С. 21.

Краев Д. Ю. Проблемы уголовной ответственности за убийства, сопряженные с иными преступлениями.-М.: Юрлитинформ, 2009.- С. 89; Попов А.Н. Убийства при отягчающих обстоятельствах.-СПб.: Юридический центр Пресс, 2003.-С. 324.

${ }^{8}$ Волженкин Б.В. Принцип справедливости и проблемы множественности преступлений по УК РФ // Законность. - 1998. - № 12.— С. 2-7; Стетюха М.П. Убийства, сопряженные с изнасилованием и (или) насильственными действиями сексуального характера: уголовно-правовые и криминологические аспекты: автореф. дисс. ... канд. юрид. наук.— Ростовна-Дону, 2008. - С. 10; Бавсун М.В., Вишнякова Н.В. Сопряженность как уголовно-правовая категория // Общество и право. - 2014.— № 4.С. 64-70; Рожнов А. П. Проблемы квалификации убийств, сопряженных с иными преступлениями // Вестник Волгоградского гос. ун-та. Сер. 5, Юриспруденция.-2011. - № 1.—C. 152-158. 
Таблица 1. Использование признака «группа» в качестве квалифицирующего

\begin{tabular}{|l|l|l|l|l|l|} 
& $\begin{array}{l}\text { группа лиц, } \\
\text { группа лиц } \\
\text { по предв-ритель- } \\
\text { ному сговору, } \\
\text { организованная } \\
\text { группа }\end{array}$ & $\begin{array}{l}\text { группа лиц, группа } \\
\text { лиц по предвари- } \\
\text { тельному сговору }\end{array}$ & $\begin{array}{l}\text { группа лиц по пред- } \\
\text { варитель-ному } \\
\text { сговору, организо- } \\
\text { ванная группа }\end{array}$ & $\begin{array}{l}\text { группа лиц по пред- } \\
\text { варительному } \\
\text { сговору }\end{array}$ & $\begin{array}{l}\text { организованная } \\
\text { группа }\end{array}$ \\
\hline $\begin{array}{l}\text { в части статьи как } \\
\text { квалифицирующий } \\
\text { признак }\end{array}$ & $\begin{array}{l}105,131,132,142.2 \\
\text { (ст. УК РФ) }\end{array}$ & $\begin{array}{l}110,110.1,117,141, \\
146,147,151.2\end{array}$ & 126,127 & $126,127,127.1$, \\
\hline $\begin{array}{l}\text { в части статьи } \\
\text { как особо ква- } \\
\text { лифицирующий } \\
\text { признак }\end{array}$ & 134 & 111,135 & 127.2 \\
\hline
\end{tabular}

да законодатель повышает наказание в санкции ч. 2 ст. 105 УК РФ за счет «сопряженности», а затем требует и применения правил ст. 69 УК РФ при назначении наказания по совокупности двух сопряженных преступлений.

Дифференцирующие ответственность обстоятельства, чтобы претендовать на роль квалифицирующих признаков, должны быть свойственны лишь определенной группе преступлений и соотносимы с тем или иным признаков состава преступления. В случае, когда эти условия не выполняются, но потребность в дифференциации ответственности сохраняется, законодатель может воспользоваться иными средствами, в частности, предусмотреть соответствующие правила в ряду предписаний Общей части уголовного закона. В ряду признаков, регламентация которых в этой части нуждается в оптимизации, следует назвать групповой характер преступления и наличие судимости у субъекта преступления.

Дифференциация ответственности за преступление, совершенное в составе различных групповых образования, является одним из наиболее распространенных оснований для конструирования квалифицирующих признаков. В том или ином сочетании и виде признак «группа лиц» отражен в ст.ст. 105, 110, 110.1, 111, 112, 117, 126, 127, 127.1, 127.2, 131, 132, 134, 135, 141, 142.2, 146, $147,151.2$ УК РФ. При этом, как показывает анализ, сочетания различных групп и оценка деяний, ими совершенных, в законодательстве существенно различается применительно к различным преступлениям (см. табл. 1).

Таблица наглядно демонстрирует, что использование рассматриваемого признака не подчиняется законам формальной логики и является достаточно произвольным ${ }^{1}$. Так, например, один и тот же набор признаков мо-

\footnotetext{
См. об этом также: Соболев В. В. Основание и дифференциация ответственности соучастников преступления: автореф. дисс. ... канд. юрид. наук.-Краснодар, 2000.-С. 22.
}

жет выступать как квалифицирующим, так и особо квалифицирующим обстоятельством (например, в ст. 110 и ст. 111 УК РФ); применительно к сходным по своим параметрам преступлениям могут использоваться различные сочетания признаков для дифференциации ответственности в качестве особо квалифицирующего обстоятельства (например, в ст. 134 и ст. 135 УК РФ); различные группы могут выступать и в качестве квалифицирующего, и в качестве особо квалифицирующего обстоятельства (например, в ст. 105 и ст. 126 УК РФ); допускается как недифференцированная оценка групповых преступлений, совершенных в различных группах 2 (ст. 105 УК РФ), так и дифференциация ответственности в зависимости от вида группы (ст. 126 УК РФ); возможно использование как всего набора групп, так и лишь одной группы (например, ст. 131 и ст. 127.1 УК РФ).

Вряд ли можно объяснить такую ситуацию криминологическими и социально-правовыми особенности преступлений. При всем желании сложно обосновать отсутствие признака «совершение преступления в группе лиц без предварительного сговора» В ст.ст. 111, 135, 141 УК РФ; нет разумных объяснений для существующих различий в оценках групповых случаев вовлечения несовершеннолетних в различные действия, причиняющие вред их нравственному и физическом у развитию; нет оснований для унификации ответственности за убийство, совершенное в различных формах соучастия и т.д.

Представляется, что поиск оправдывающих законодателя оснований в данном случае бесперспективен.

\footnotetext{
На этот счет в науке уже отмечалось, что «нивелирование законодателем пределов ответственности участников различных по уровню общественной опасности групповых преступных образований, когда в ряде статей Особенной части УК РФ виды преступной группы изложены в одной части (пункте) и равным образом влияют на наказание, представляется неудачным». См.: Балеев С.А. Дифференциация ответственности соучастников преступления // Ученые записки Казанского гос. ун-та.— 2007.-Т. 149. Кн. 6. Гуманитарные науки.-C. 204.
} 
А потому требуется некоторое общее решение проблемы, формулировка неких общих принципов и начал дифференциации уголовной ответственности за преступление, совершенное в соучастии. Исходной посылкой к разработке таких правил должно стать признание очевидного факта: преступление, совершенное в группе, обладает сравнительно большей общественной опасностью, нежели преступление, совершенное лицом единолично. Опасность умножается за счет увеличения числа участвующих в преступлении лиц, углублении содержания их вины, большей вероятности причинения вреда, оптимизации механизма совершения преступления, ограничения возможности потерпевшего избежать преступления. Очевидно, что в силу этого едва ли возможно признавать рассматриваемый квалифицирующий признак в качестве характеризующего исключительно субъекта преступления ${ }^{1}$ или объективную сторону деяния ${ }^{2}$, как это предлагается в литературе. Он демонстрирует качественно-количественное изменение всех параметров и показателей общественной опасности, а потому носит универсальный характер.

Это дает основание к разработке общих правил дифференциации ответственности за совершение в составе группы лиц (любых форм) всех преступлений. Попытки их создания предприняты в науке. Так, В.В. Соболев предлагает дополнить ст. 67 УК РФ дифференцированными правилами определения минимального срока наказания за преступления, совершенные, с одной стороны, в группе лиц и группе лиц по предварительному сговору, а с другой стороны - организованной группой ${ }^{3}$. Еще более дробит такие правила Н.В. Димченко, определяя минимум наказания в определенном процентном отношении от максимума санкции 4 . О разработке соответствующих правил пишут и иные авторы ${ }^{5}$.

Однако важно подчеркнуть, что все эти предложения разрабатываются, по большому счету, вне анализа проблемы дифференциации уголовной ответственности посредством квалифицирующих признаков. Специалисты, в частности, не оспаривают сам факт наличия квалифицирующего признака «группа» и более того, предлагают указать этот признак в целом ряде статей уголовного за-

\footnotetext{
1 Лопашенко Н. А. Убийства.- М.: Юрлитинформ, 2013.

2 Борзенков Г.Н. Преступления против жизни и здоровья: закон и правоприменительная практика.-М.: ИКД «Зерцало-М», 2009.

${ }^{3}$ Соболев В.В. Основание и дифференциация ответственности соучастников преступления: автореф. дисс. ... канд. юрид. наук. - Краснодар, 2000.- С. 23. ${ }^{4}$ Димченко Н. В. Ответственность за преступления, совершенные в соучастии: теоретические и прикладные аспекты: дисс. ... канд. юрид. наук.- М., 2006.- С. 12

${ }_{5}^{5}$ Сидирякова М. В. Назначение наказания участникам групповых преступлений: дисс. ... канд. юрид. наук.-Казань, 2003.- С. 10; Кубов Р.Х. Особенности квалификации сложных форм соучастия: автореф. дис. ... канд. юрид. наук.-М., 2003.- С. 19-20.
}

кона. Такие разработки не отвечают, как представляется, началам системности. Более того, разработка и применение дифференцированных правил назначения наказания при сохранении квалифицированных составов с повышенной санкцией с неизбежностью повлечет за собой нарушение принципа справедливости и двойной учет одного и того же обстоятельства.

В связи с этим более разумным и обоснованным видится следующее комплексное решение проблемы: а) исключение квалифицирующего признака «совершение преступления группой лиц, группой лиц по предварительному сговору, организованной группой» (во всех комбинациях) из всех статей Особенной части УК РФ; б) разработка и закрепление в ст. 67 УК РФ правила об обязательном усилении наказания в случае совершения группового преступления (по аналогии с положениями ст. 68 УК РФ, с дифференциацией минимального предела наказания в зависимости от формы соучастия). Это повлечет за собой: а) обязательную ссылку при квалификации содеянного на соответствующую часть ст. 33 УК РФ во всех случаях, когда лицо, не является исполнителем преступления (в том числе и для преступлений, совершенных организованной группой $)^{6}$; б) обязательное доказывание в судебной процедуре формы соучастия и ссылку на ст. 67 УК РФ при назначении наказания7; в) усиление ответственности за все без исключения преступления, в случае совершения их в группе лиц; г) последовательную дифференциацию ответственности в зависимости от общественной опасности той или иной формы соучастия.

Еще один квалифицирующий признак преступлений против личности, который может быть в перспективе более детально регламентирован на уровне предписаний Общей части УК РФ — предшествующая судимость субъекта преступления. Сегодня в Разделе VII УК РФ этот признак встречается только в составах половых преступлений против несовершеннолетних (ч. 5 ст. 131, ч. 5 ст. 132, ч. 6 ст. 134, ч. 5 ст. 135 УК РФ) 8 .

В отечественной литературе (особенно советского периода истории и на рубеже XXI века) была представлена широкая дискуссия о содержании данного при-

\footnotetext{
Такие предложения уже обоснованно выдвигались в науке ранее, см., например: Кисин А. В. Уголовная ответственность за преступления, совершенные в составе организованной преступной группы: автореф. дисс. канд. юрид. наук.- М., 2013.- С. 9.

${ }^{7}$ Современная редакция ст. 67 УК РФ справедливо воспринимается в науке как неинформативная и не требующая применения при назначении наказания соучастникам, см. об этом: Соучастие в преступлении: проблемы квалификации и назначения наказания / под ред. Ю. Е. Пудовочкина.- М.: РГУП, 2019.- С. 483 (автор соответствующего раздела - А. А. Толкаченко). ${ }^{8}$ Наряду с этим, он использован еще в трех статьях закона, регламентирующих ответственность за мелкое взяточничество, мелкий коммерческий подкуп и нарушение правил дорожного движения.
} 
знака и возможности его использования в уголовном законе в качестве квалифицирующего обстоятельства. Персональная редакция УК РФ, как известно, отказалась от его использования, однако спустя двадцать лет, законодатель вновь вернулся к его использованию. Сегодня толкование этого признака дано в постановлении Пленума Верховного Суда РФ, посвященном квалификации половых преступлений. Согласно п. 14 соответствующего Постановления, к имеющим судимость за ранее совершенное преступление против половой неприкосновенности несовершеннолетнего относятся лица, имеющие непогашенную или не снятую в установленном порядке судимость за любое из совершенных в отношении несовершеннолетних преступлений, предусмотренных частями 3-5 статьи 131, частями 3-5 статьи 132, частью 2 статьи 133, статьями 134, 135 УК РФ. При этом также учитываются судимости за указанные преступления, совершенные лицом в возрасте до восемнадцати лет'. В постановлении Пленума ВС РФ, посвященном вопросам назначения наказания, специально подчеркивается, что «в случае совершения преступления против половой неприкосновенности потерпевших, не достигших четырнадцатилетнего возраста, квалифицированного по части 5 статьи 131 УК РФ или по части 5 статьи 132 УК РФ, лицом, имеющим судимость за ранее совершенное преступление против половой неприкосновенности несовершеннолетнего, суд не вправе учитывать такую судимость в качестве отягчающего наказание обстоятельства, предусмотренного пунктом «а» части 1 статьи 63 УК РФ» (п. 32) $)^{2}$.

Исходя из текста закона и разъяснений высшей судебной инстанции, квалифицирующий признак наличия предшествующей судимости не всегда образует рецидив преступлений. В связи с чем вновь актуализируется вопрос о возможности применения положений ст. 68 УК РФ к лицам, чьи действия квалифицированы с учетом рассматриваемого квалифицирующего признака, и в чьем поведении наличествуют признаки рецидива (ст. 18 УК РФ). Это одна из «старых проблем» отечественного уголовного права, восходящая к соотношению «неоднократности» и «рецидива» ${ }^{3}$. Действовавшее в условиях прежнего (до реформы 2003 года) законодательство и практика его применения допускали возможность «двойного» учета этих обстоя-

\footnotetext{
1 Постановление Пленума Верховного Суда РФ от 04.12.2014 № 16 «О судебной практике по делам о преступлениях против половой неприкосновенности и половой свободы личности» // Бюллетень Верховного Суда РФ._- 2015.— № 2.

2 Постановление Пленума Верховного Суда РФ от 22.12.2015 № 58 «О практике назначения судами Российской Федерации уголовного наказания» // Бюллетень Верховного Суда РФ.— 2016. — № 2.

${ }^{3}$ См., например, об этом: Становский М.Н. Назначение наказания.- СПб: Юридический центр Пресс, 1999.-С. 241-247; Зубкова В.И. Уголовное наказание и его социальная роль: теория и практика.- М.: Норма, 2002.С. 251-252; Бытко Ю.И. Учение о рецидиве преступлений в российском уголовном праве.-Саратов: Саратовск. гос. акад. права, 1998.—C. 179.
}

тельств ${ }^{4}$. Сегодня к этому также есть предпосылки. Если наличие судимости как признак, позволяющий вменить исследуемое квалифицирующее обстоятельство, не образует для лица рецидива, применяется только соответствующая статья Особенной части УК РФ с назначением наказания в пределах санкции; если же эта судимость одновременно образует рецидив, то помимо квалификации содеянного с учетом квалифицирующего признака, суд должен констатировать рецидив (ст. 18 УК РФ), признать его отягчающим обстоятельством (ст. 63 УК РФ) и назначить наказание с учетом правил определения наказания при рецидиве (ст. 68 УК РФ). Такое положение вещей, как представляется, нарушает и принцип равенства граждан перед законом, и принцип справедливости. Оно не может быть оправданно социально-психологическими переживаниями и эмоциями в связи с защитой несовершеннолетних от сексуального совращения и сексуальной эксплуатации.

К тому же признак «специального рецидива» (в криминологическом смысле он охватывает содержание исследуемого квалифицирующего обстоятельства) в большей степени характеризует опасность личности виновного, нежели свидетельствует о возрастании опасности самого преступления. Как мы уже отмечали, дифференциация уголовной ответственности в зависимости от свойств личности виновного вполне оправданна, но она не должна предполагать использования квалифицирующих признаков в качестве своего инструмента.

Не оспаривая представлений о повышенной опасности лиц, которые неоднократно, при наличии судимости совершают тождественные преступления, полагаем, что качественная оценка такой опасности должна быть учтена в нормах Общей части УК РФ, прежде всего, за счет существенной модернизации института рецидива преступлений ${ }^{5}$. В науке имеются, на наш взгляд, впол-

\footnotetext{
${ }^{4}$ Так, согласно п. 11 постановления Пленума Верховного Суда РФ от 11.06.1999 № 40 «О практике назначения судами уголовного наказания» (Бюллетень Верховного Суда РФ. - 1999._ № 9), правила, изложенные в ч. 3 ст. 68 УК РФ, применялись лишь в случаях, когда статья (или часть статьи) Особенной части УК РФ содержала указание на судимость лица как на квалифицирующий признак при совершении нового преступления (например, пункт «В» части третьей статьи 158 УК РФ, пункТ «В» части третьей статьи 159 УК РФ, пункт «В» части второй статьи 213 УК РФ). А в соответствии с п. 13 Постановления, в случаях, когда основанием для квалификации действий лица по признаку совершения преступления неоднократно явилась предшествующая судимость, которая не была погашена или снята, судам надлежало в соответствии со Ст. 18 УК РФ решить вопрос о наличии рецидива преступлений и его вида. При наличии рецидива преступлений, назначая наказание, следовало руководствоваться ч. 2 ст. 68 УК РФ, если статья (часть статьи) Особенной части УК РФ не содержит указания на судимость лица, совершившего преступление, как квалифицирующий признак.

${ }^{5}$ В науке представлена и принципиально иная позиция — «включить в описание составов преступлений против жизни, против собственности и других преступлений, часто совершаемых лицами, ранее судимыми за аналогичные деяния, такой признак, как рецидив». См.: Татарников В.Г. Рецидив и его влияние на характер и степень общественной опасности преступлений против личности // Вестник ИрГТУ.- 2015.— № 6.-С. 284-288.
} 
не убедительные свидетельства того, что оптимальным ответом на опасность таких лиц может стать концепция рецидивиста ${ }^{1}$. В рамках ее построения есть все основания к тому, чтобы формировать специальные правила дифференциации уголовной ответственности для лиц, которые имеют судимость и неоднократно совершают преступные деяния, не прибегая при этом к конструированию квалифицирующих признаков. Это позволит: а) учесть криминальную специализацию и признавать рецидивистами лишь тех, кто, имея судимость, совершает тождественные или однородные преступления; б) обеспечить дифференциацию ответственности рецидивистов в случае совершения ими любых преступлений (не только против личности, но и против иных объектов); в) рассмотреть и решить вопрос относительно учета для признания лица рецидивистом судимостей за преступления, совершенные лицом в возрасте до 18 лет².

\section{ЛИТЕРАТУРА}

1. Андрюхин Н. Г. Дифференциация уголовной ответственности и наказания несовершеннолетних: состояние и перспективы развития. — М.: ВНИИ МВД РФ, 2004. - $151 \mathrm{c}$.

2. Армашова А. В. Проблемы рецидива преступлений и ответственности за него по уголовному праву России: автореф. дисс. ... канд. юрид. наук. — Рязань, 2006. - $28 \mathrm{C}$.

3. Арсанукаев И.С. Криминологическое и уголовно-правовое исследование предупреждения убийств, сопряженных с другими преступлениями: дисс. ... . канд. юрид. наук.- М., 2012. - 195 с.

4. Бавсун М.В., Вишнякова Н. В. Сопряженность как уголовно-правовая категория // Общество и право.— 2014. — № 4. — C. 64-70.

5. Балеев С. А. Дифференциация ответственности соучастников преступления // Ученые записки Казанского гос. ун-та. - 2007. - Т. 149. Кн. 6. Гуманитарные науки.- С. 200-204.

6. Борзенков Г. Н. Преступления против жизни и здоровья: закон и правоприменительная практика.— М.: ИКД «Зерцало-М», 2009. — 256 с.

7. Бородин С. В. Преступления против жизни.-М.: Юристъ, 1999.- 356 с.

8. Бытко Ю. И. Учение о рецидиве преступлений в российском уголовном праве. — Саратов: Саратовск. гос. акад. права, 1998. — 220 с.

9. Васяев Д. В. Уголовная ответственность за убийство с учетом его мотива и цели: проблемы правотворчества и правоприменения: автореф. дисс. ... канд. юрид. наук.-Самара, 2014.- 21 с.

10. Волженкин Б. В. Принцип справедливости и проблемы множественности преступлений по УК РФ // Законность. — 1998. — № 12.— С. 2-7.

11. Димченко Н. В. Ответственность за преступления, совершенные в соучастии: теоретические и прикладные аспекты: дисс. ... канд. юрид. наук.- М., 2006. - $188 \mathrm{c}$.

12. Досаева Г. С. Уголовно-правовой институт множественности преступлений: автореф. дисс. ... д-ра юрид. наук. — М., 2017. — 64 с.

13. Зубкова В. И. Уголовное наказание и его социальная роль: теория и практика. — М.: Норма, 2002. — 296 с.

14. Иванов Н.Г. К вопросу о квалификации «преступлений сопряженности» // Вестник Академии Генеральной прокуратуры Российской Федерации. Научно-практический журнал.—М., 2007.— № 2 (2).- С. 38-42.

15. Иногамова-Хегай Л. В. Концептуальные основы конкуренции уголовно-правовых норм. — М.: Норма, 2015. — 287 с.

16. Комментарий к Уголовному кодексу Российской Федерации (постатейный). В 2 т. Т. 1. / под ред. А. В. Бриллиантова. 一 Изд. 2-е. 一 М.: Проспект, 2015. 792 c.

17. Комментарий к Уголовному кодексу Российской Федерации. В 4 т. Т. 2. Особенная часть. Разделы VII — VIII / отв. ред. В. М. Лебедев. — М.: Юрайт, 2017. 371 c.

18. Кисин А. В. Уголовная ответственность за преступления, совершенные в составе организованной преступной группы: автореф. дисс. ... канд. юрид. наук. - М., 2013. - $28 \mathrm{c}$.

19. Коротких Н. Н. Теоретические и прикладные проблемы учения о множественности преступлений: уголовно-правовое и уголовно-исполнительное исследование: автореф. дисс. ... д-ра юрид. наук. — Екатеринбург, 2016. - 39 с.

20. Краев Д. Ю. Проблемы уголовной ответственности за убийства, сопряженные с иными преступлениями. - М.: Юрлитинформ, 2009. - 220 с.

21. Кубов Р. Х. Особенности квалификации сложных форм соучастия: автореф. дис. ... канд. юрид. наук.— М., 2003.— 26 с.

22. Лопашенко Н. А. Убийства. - М.: Юрлитинформ, 2013. - 540 с.

\footnotetext{
См. об этом: Щербаков С.В. Рецидивная преступность: криминологическая характеристика и проблемы предупреждения: автореф. дисс. ... канд. юрид. наук.- М., 2009; Меликов Э. М. Рецидив краж: уголовная ответственность и предупреждение: автореф. дисс. ... канд. юрид. наук.-М., 2017; Досаева Г.С. Уголовно-правовой институт множественности преступлений: автореф. дисс. ... д-ра юрид. наук.- М., 2017; Понятовская Т.Г. Проблема рецидива в уголовном праве и криминологии // Криминологический журнал Байкальского государственного университета экономики и права. - 2014. - № 3 с. 96-102.
}

\footnotetext{
2 Такие предложения разработаны в науке, см.: Армашова А. В. Проблемы рецидива преступлений и ответственности за него по уголовному праву России: автореф. дисс. ... канд. юрид. наук. - Рязань, 2006; Андрюхин Н.Г. Дифференциация уголовной ответственности и наказания несовершеннолетних: состояние и перспективы развития.- М.: ВНИИ МВД РФ, 2004.-C. 134
} 
23. Малков В. П. Институт множественности преступлений в доктрине и уголовном законодательстве России // Актуальные проблемы экономики и права. 2008. - № 4.- - С. 179-192.

24. Меликов Э. М. Рецидив краж: уголовная ответственность и предупреждение: автореф. дисс. ... канд. юрид. наук. — М., 2017.— 25 с.

25. Понятовская Т. Г. Проблема рецидива в уголовном праве и криминологии // Криминологический журнал Байкальского государственного университета экономики и права. - 2014. - № 3- С. 96-102.

26. Попов А. Н. Убийства при отягчающих обстоятельствах. - СПб.: Юридический центр Пресс, 2003. - 896 с.

27. Плаксина Т. А. Социальные основания квалифицирующих убийство обстоятельств и их юридическое выражение в признаках состава преступления: автореф. дисс. ... д-ра юрид. наук. - Томск, 2006. - 46 с.

28. Рожнов А. П. Проблемы квалификации убийств, сопряженных с иными преступлениями // Вестник Волгоградского гос. ун-та. Сер. 5, Юриспруденция. 2011. — № 1.—C. 152-158.

29. Сидирякова М. В. Назначение наказания участникам групповых преступлений: дисс. ... канд. юрид. наук.— Казань, 2003. — 213 с.

30. Соболев В. В. Основание и дифференциация ответственности соучастников преступления: автореф. дисс. ... канд. юрид. наук. - Краснодар, $2000 .-24$ с.

31. Соучастие в преступлении: проблемы квалификации и назначения наказания / под ред. Ю. Е. Пудовочкина.— М.: РГУП, $2019 .-507$ с.

32. Становский М. Н. Назначение наказания. — СПб.: Юридический центр Пресс, 1999. — 458 с.

33. Стетюха М. П. Убийства, сопряженные с изнасилованием и (или) насильственными действиями сексуального характера: уголовно-правовые и криминологические аспекты: автореф. дисс. ... канд. юрид. наук. — Ростов-на-Дону, 2008. — 24 с.

34. Татарников В.Г. Рецидив и его влияние на характер и степень общественной опасности преступлений против личности // Вестник ИрГТУ.- 2015.— № 6. - С. 284-288.

35. Фристер Г. Уголовное право Германии. Общая часть. - 5-е изд.- М.: Инфотропик, 2013. - 712 c.

36. Щепельков В. Ф. Уголовный закон: преодоление противоречий и неполноты.- М.: Юрлитинформ, 2003. - 413 c.

37. Щербаков С. В. Рецидивная преступность: криминологическая характеристика и проблемы предупреждения: автореф. дисс. ... канд. юрид. наук.— М., 2009. - $26 \mathrm{C}$.

38. Шкредова Э.Г. Формы множественности преступлений в современной уголовно-правовой доктрине // Журнал Российского права. — 2012.— № 9.— C. 50-54.

(c) Мотин Анатолий Владимирович ( amotin85@yandex.ru).

Журнал «Современная наука: актуальные проблемы теории и практики»

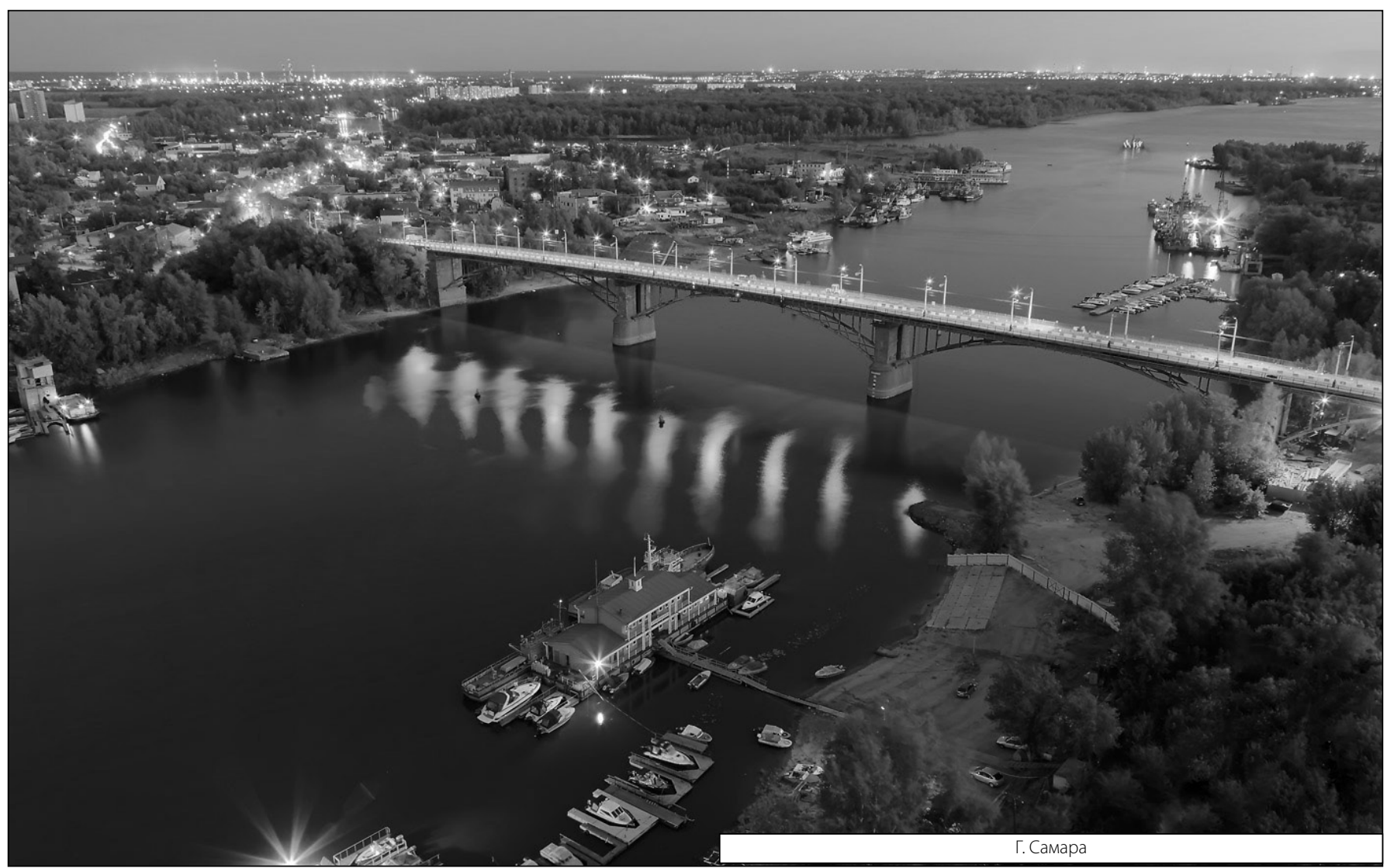

